\title{
Evaluation of semen for breeding soundness of four different breeds of bull used for artificial insemination
}

\author{
Md. Atiqur Rahman ${ }^{1}$, Nasrin Sultana Juyena ${ }^{2}$, Jalal Uddin Ahmed ${ }^{3}$, Raihana \\ Nasrin Ferdousy ${ }^{4}$, Sumen Chakma ${ }^{5}$, Md. Zinnu Rine ${ }^{6}$ and \\ Abu Md. Mamun Tarif ${ }^{7}$ \\ ${ }^{1234567}$ (Department of Surgery and Obstetrics, Bangladesh Agricultural University, Bangladesh)
}

\begin{abstract}
The investigation was aimed to evaluate the bulls for breeding soundness by assessing their fresh semen. The study was performed in District AI center, Mymensingh and AI center,BAU, Mymensingh. Four different bulls of cross breed (Holstein-Friesian $\times$ Zebu, Sahiwal $\times$ Zebu, Sindhi $\times$ Zebu and Red Chittagong Bull) were examined physically with a special emphasis to the palpation of the scrotum and testicles and rectal palpation of the pelvic genitalia were carried out once every two weeks. The sexual behavior particularly the libido was observed at service. A total of 107 ejaculates were collected and evaluated with respect to ejaculate volume, mass activity, sperm motility, concentration of sperm, $p H$, percentages of live and dead spermatozoa from 1 May to 31 October, 2013. The bulls used in this study were regarded as clinically normal. During the study, mean value of semen ejaculate volume, sperm motility, mass activity, sperm concentration, percentage of live and dead sperm and $\mathrm{pH}$ were $5.81 \pm 0.16 \mathrm{ml}, 66.64 \pm 0.50 \%, 3.59 \pm 0.05$, $1115.97 \pm 16.08$ million $/ \mathrm{mm}^{3}, 77.62 \pm 0.63 \%, 15 \%$ to $45 \%, 6.48 \pm 0.01$ respectively. The mean fertility rate

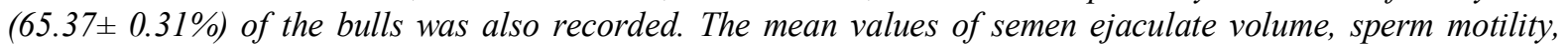
mass activity, sperm concentration, percentage of live sperm and dead sperm, $p H$ and fertility varied significantly $(p<0.01)$ among breeds. Significantly $(P<0.01)$ the highest volume per ejaculation, sperm concentration, mass activity were found in Holstein cross and lowest in Red Chittagong breeds of bulls. Significantly $(P<0.05)$ the highest live spermatozoa percentage, $p H$, fertility rate were found in Holstein Friesian $\times$ Zebu and lowest in Red Chittagong breeds of bulls. It was concluded that the Holstein - Friesian $\times$ Zebu crossbred bull produced better quality semen in comparison to other breed. So, it can be suggested that, Holstein - Friesian $\times$ Zebu crossbred bull could be suitable as breeding bull to be used for AI.
\end{abstract}

Keywords: bull, artificial insemination, breeding soundness, concentration, morphology, motility

\section{Introduction}

The livestock population in Bangladesh has been estimated to be about 49 millions of which the population of cattle is about 29 millions (Directorate of Livestock Services, 2012-13). The cattle supply milk and meat for human consumption, hides and other raw materials for industry, manure and draught power for crop production and fuel for domestic use. Reproductive technologies and innovative breeding in livestock production are as fundamental for global food security [1]. Artificial insemination (AI) has been using as a tool for sound breeding programme. Selection of sound bull is one of the most important decisions of sound breeding programme. Quality evaluation of semen is one of the most important steps to detect the breeding soundness of bulls which determines bulls' health, physical and reproductive soundness. A bull requires the following criteria to be fertile: physical soundness, good libido, and good quality semen [2]. Sub-fertility in bull's delays pregnancy, prolongs calving interval, reduces calf weaning weight and increases culling rate of females. In Bangladesh, cross breeding for upgradation of cattle was started in 1935 with a view to improve the local cattle stock [3]. with no systematic sexual health control programme. Because of low uptake of AI in smallholdings, production per animal has been remained very low. To overcome this, a programme should be undertaken for improvement of cattle in Bangladesh, especially indigenous cattle. If pregnancy does not result from the minimum number of services, it constitutes an economic loss to the farmer. AI must be combined with a health control programme, which must take care of sub-fertility problems. AI continues to be the most effective weapon in the control of venereal and other diseases. Single bull in AI centre can produce 100000 doses of semen per year. A single collection of semen may yield over a thousand doses, which may be widely distributed over a long period. Extremely low reproductive rates in tropical location are often blamed on female cattle, although it may be assumed that climate and poor health may also influence the fertility of bulls, especially semen quality and libido [4]. In Bangladesh, comprehensive work has not been done with regard to quality of semen and fertility of 
cattle by AI. The investigation was aimed to evaluate fresh semen to be used for insemination in a routine Al programme. The study was undertaken to compare the quality of semen among four different breeds of bull and to evaluate bulls for breeding soundness.

\subsection{Study area and period}

\section{Materials And Methods}

The present study was conducted at Bangladesh Agricultural University AI Center and district AI center, Mymensingh from 1 May to 31 October, 2013.

\subsection{Experimental bulls}

Experimental bulls were Holstein Friesian $\times$ Zebu (Bull No. 862), Sahiwal $\times$ Zebu (Bull No. 79), Sindhi $\times$ Zebu (Bull No. 122), Red Chittagong (Bull No. 178). The age of the bulls were determined by the date of birth from the record book maintained by AI center and ranged from 36 to 90 months. Detailed information on each bull such as age, body weight, health status, vaccination was obtained from the record books of the bull station.

\subsection{Examination of bulls}

Before introduction to the collection schedule, the bulls were examined physically with a special emphasis to the palpation of the scrotum and testicles and rectal palpation of the pelvic genitalia were carried out once every two weeks. The sexual behaviour of the bulls was observed, including libido, erection, mounting and grasping of the dummy, protrusion of penis and thrust and ejaculation. The scrotum was inspected with respect to size, shape and freedom from skin disease.

\subsection{Physical examination}

The examination was based on internal and external component.

- Internal - A transrectal examination was used to evaluate the health of secondary sex organs - urethra, prostate, seminal vesicles, ampullae and vas deferens.

- External - Palpation of the testicles and epidiymis and examination of the sheath and penis were done to detect abnormalities that could affect breeding performance.

\subsection{Clinical Examination of Bulls}

The bulls were thoroughly examined especially with regard to the locomotion body condition score, rectal temperature, breathing rate and pulse rate. The nutrition condition of the bulls was scored into 1-5 scale [5]. The bulls used to be weighed routinely once in a month. The scrotum of bulls was inspected with respect to size, symmetry and any visible skin diseases. The consistency of testes was assessed on the basis of firmness and resilience into $1-5$ scale.

\subsection{Semen collection}

The semen was collected thrice week by means of AV (artificial vaginal method) [6]. The liner of the AV was filled with water at 42-48 degrees Celsius, and the inner surface was lubricated with something like $\mathrm{K}$ $\mathrm{Y}$ jelly. The internal temperature of $\mathrm{AV}$ was checked to ensure that it was not above $50^{\circ} \mathrm{C}$. The AV was held upright to flow the ejaculate into graduated tube which was attached with the latex extension cone. An insulating cone was placed over the end from which the collection tube protrudes to avoid subjecting the semen to temperature shock. About 107 ejaculates were collected from 4 different breeds of bull.

\subsection{Volume and macroscopic examination}

The volume, colour and opacity of the semen and presence of any foreign substances were checked according to [7]. The density of the ejaculate reflects sperm concentration, which was expressed with "D". The sperm concentration was determined by a haemocytometric method [8]after dilution 1:200 with buffered formalsaline. The samples of semen with concentration above $1000 \mathrm{million} / \mathrm{mm}^{3}$ were considered as good. A drop of undiluted semen was placed on a warmed $\left(37^{\circ} \mathrm{C}\right)$ slide without cover slip and examined with low power objective (100) as described by [9]. The mass activity was graded as $1-5$ scale $(1+=$ No mass activity , $2+=$ Slow wave motion, $3+=$ Rapid wave motion with formation of eddies at the end of waves, $4+=$ Eddies). Motility was evaluated in a small drop of semen under cover slip with higher magnification (400). Sperm moving forward were included in the motility count while sperm moving in circles or backward or showing pendulating movement were excluded (Herman et al., 1994). The sperm cell concentration was estimated by haematocytometer after dilution 1:200 with buffered formal - saline. The $\mathrm{pH}$ was measured using indicator paper strips. The percent of live sperm cells was determined from a Live - dead count of 500 spermatozoa on semen sample with eosin nigrosin stain. 


\subsection{Statistical analyses}

All values relating to semen evaluation parameter were expressed as mean \pm standard error mean (SEM). The findings in all cases were subjected to statistical analysis. Paired ' $T$ ' test was performed to obtain the difference in volume per ejaculate, mass activity ,motility, sperm concentration, live sperm percentage, dead sperm percentage and fertility rate among breeds.

\section{Results And Discussion}

The general health conditions of bulls were found to be good. The confirmation of the locomotory organs of all bulls was found to be normal. Sexual behaviour of the bulls like libido, erection and protrusion of the penis, mounting and grasping of the dummy, seeking movement, thrust and ejaculation were found to be satisfactory. The bulls were all free from venereal diseases. The health of the bulls was good, as suggested by the Theriogenology Society in the United States of America (Kastelic and Thundathil, 2008). Sexual behaviour of all the bulls was satisfactory. The scrotal sac was normal and no skin lesion was detected. Observation of mating performance and behaviour and semen evaluation are traditionally used to assess bulls for suitability for breeding (Parkinson, 2004). Britol et al. (2004) found that scrotal circumference was a good predictor of sexual maturity in Bos indicus bulls. Chacon et al. (2002) observed that scrotal circumference is positively related to body condition in Brahman bulls in tropics and commented that nutrition may be a major factor affecting seasonal variations in male reproductive parameters, especially testicular size. Santos et al. (1998) found that those bull fed high levels of concentrates had higher body weight and scrotal circumference than those fed low levels, but there was no difference in semen turbidity, motility and sperm concentration. As scrotal circumference increases, age at puberty decreases and productivity is improved in daughters.

\section{Semen evaluation}

Table-1: Values (Mean \pm SEM, Minimum value, Maximum value) of different parameters of semen during study.

\begin{tabular}{|l|c|c|c|}
\hline \multicolumn{1}{|c|}{ Parameters } & Mean \pm SEM & Minimum value & Maximum value \\
\hline Volume (ml) & $5.81 \pm 0.16$ & 2.00 & 8.50 \\
\hline Motility (\%) & $66.64 \pm 0.50$ & 55 & 75 \\
\hline Mass activity & $3.59 \pm 0.05$ & 2 & 4 \\
\hline Concentration (million $/ \mathrm{mm}^{3}$ ) & $1115.97 \pm 16.08$ & 800 & 1775 \\
\hline $\mathrm{pH}$ & $6.48 \pm 0.01$ & 6.00 & 6.70 \\
\hline Live spermatozoa (\%) & $77.62 \pm 0.63$ & 55 & 85 \\
\hline Dead spermatozoa (\%) & $22.38 \pm 0.63$ & 15 & 45 \\
\hline Fertility rate (\%) & $65.48 \pm 0.31$ & 45.00 & 80.0 \\
\hline
\end{tabular}

During study, the mean semen volume was $5.81 \pm 0.16 \mathrm{ml}$ in four different breeds of bulls and ranged from $2.00 \mathrm{ml}$ to $8.50 \mathrm{ml}$. The mean value of semen motility was found $66.64 \pm 0.50 \%$ in four different breeds of bulls and the motility was ranged from $55 \%$ to $75 \%$. The mass activity of semen was $3.59 \pm 0.05$ in four different breeds of bulls and the mass activity was ranged from 2 to 4 . The mean semen concentration of four different breeds of bulls was observed $1115.97 \pm 16.08 \mathrm{million} / \mathrm{mm} 3$ and which ranged from 800 to $1775 \mathrm{million} / \mathrm{mm} 3$. The mean value of $\mathrm{pH}$ of semen was $6.48 \pm 0.01$ in four different breeds of bulls and ranged from 6.00 to 6.70 . The mean value of live and dead spermatozoa were noted to be $77.62 \pm 0.63 \%$ and $22.38 \pm 0.63 \%$ which ranged from 55 to $85 \%$ and 15 to $45 \%$ respectively in four different breeds of bulls. The mean fertility rate was found $65.48 \pm 0.31 \%$ in four different breeds of bulls which ranged from 45 to $80 \%$.

Figure 1. Graphical presentation of ejaculate volume of semen of different breeds of bull.

Values are mean \pm

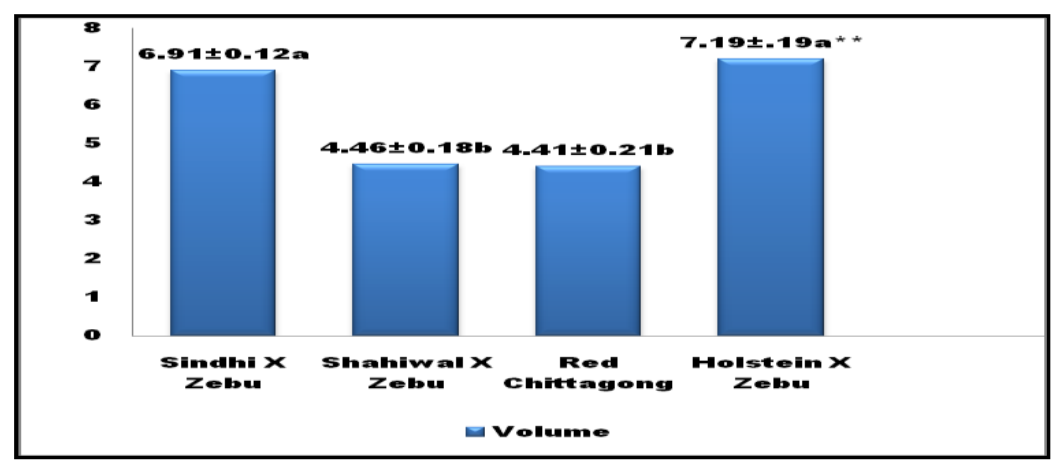

a,b indicate significant difference at $5 \%$ level $(\mathrm{P}<0.05)$

$* *$ indicate highly significant value at $1 \%$ level $(\mathrm{P}<0.01)$ 
The highest $(7.19 \pm 0.19 \mathrm{ml})$ mean value of volume of semen was found in Holstein-Friesian $\mathrm{x}$ Zebu bulls and lowest $(4.41 \pm 0.21 \mathrm{ml})$ in Red Chittagong bulls. The semen volume in other two breeds, Sindhi x Zebu and Shahiwal $\mathrm{x}$ Zebu was $6.91 \pm 0.12 \mathrm{ml}$ and $4.46 \pm 0.18 \mathrm{ml}$ respectively. There was no significant ( $\mathrm{P}>0.05$ ) difference between Shahiwal x Zebu and Red Chittagong breeds and between Sindhi x Zebu and HolsteinFriesian x Zebu breeds of bull. But semen volume of Shahiwal x Zebu and Red Chittagong breeds of bulls varied significantly $(\mathrm{p}<0.01)$ with that of Holstein-Friesian $\mathrm{x}$ Zebu breeds and Sindhi $\mathrm{x}$ Zebu breeds of bulls.

Considering the breed effect, it was found that the volume of semen varied among the breeds in this study. Reference [10] found significantly $(\mathrm{p}<0.05)$ highest $(7.6 \mathrm{ml})$ volume of semen was in Holstein-Friesian $\times$ Zebu crosses and lowest $(4.0 \mathrm{ml})$ in Sahiwal $\times$ Zebu. Reference [11] found that the mean volume of the ejaculate in adult dairy and buffalo bull was 5.4 to $6.5 \mathrm{ml}$ and 1.5 to $3.7 \mathrm{ml}$ (range: 0.5 to $6.0 \mathrm{ml}$ ) respectively. Reference [12] reported a significant $(\mathrm{P}<0.01)$ breed difference in volume of semen.

Figure 2. Graphical presentation of Motility of semen of different breeds of bull

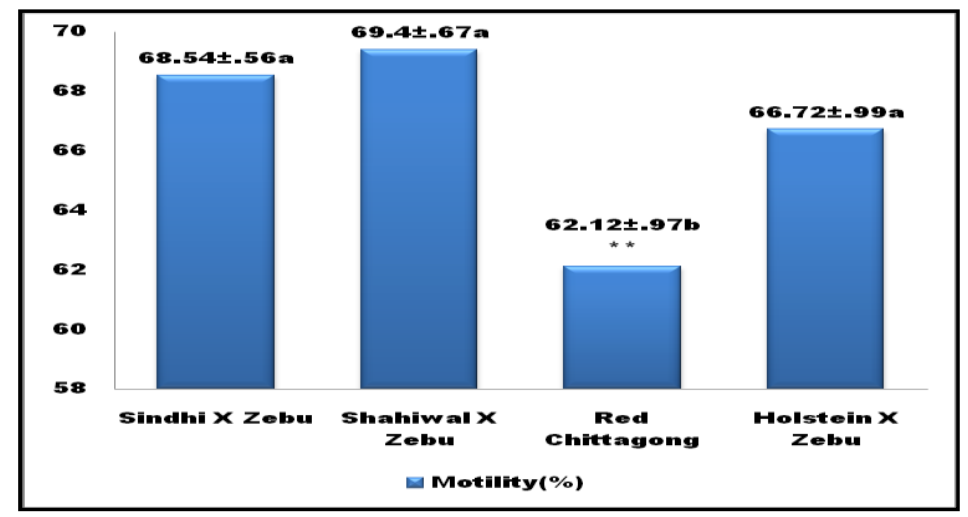

Values are mean \pm SEM

$\mathrm{a}, \mathrm{b}$ indicate significant difference at $5 \%$ level $(\mathrm{P}<0.05)$

** indicate highly significant value at $1 \%$ level $(\mathrm{P}<0.01)$

As regards to the motility of semen, the highest $(69.40 \pm 0.67 \%)$ value of motility of semen was found in Shahiwal x Zebu breeds of bulls and lowest $(62.12 \pm 0.97 \%)$ was found in Red Chittagong breeds of bulls. The value of motility of semen in other two breeds was $68.54 \pm 0.56 \%$ and $66.72 \pm 0.99 \%$ for Sindhi x Zebu and Holstein-Friesian $x$ Zebu breeds of bull respectively. There were no significant $(\mathrm{P}>0.05)$ differences among Sindhi x Zebu, Shahiwal x Zebu and Holstein-Friesian x Zebu breeds of bulls. But the motility(\%) of Red Chittagong breeds of bull differed significantly $(\mathrm{p}<0.01)$ from other three breeds of bull (Figure-12).

References [10], [13], [14], [15] reported that the percentage of motile sperm was $66.2 \%-76.0 \%$ in the Holstein-Friesian $\times$ Zebu bulls and $56.6 \%-60.1 \%$ in Jersey $\times$ Zebu bulls. Reference [16] reported that average motility of bovine fresh semen as $63.3 \%$ and the range was $50-80 \%$. This variation could be caused by the age of animals, climate and management.

Figure 3. Graphical presentation of Mass activity of semen of different breeds of bull

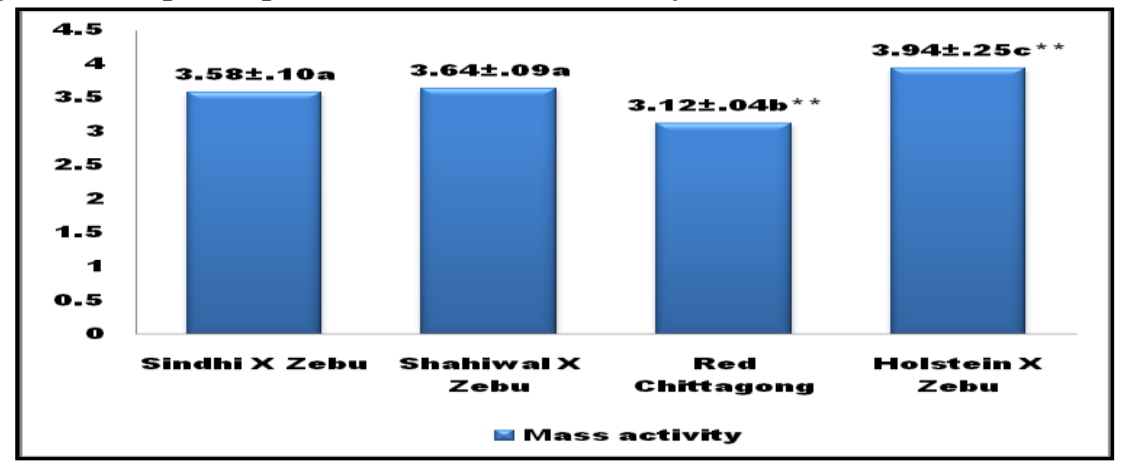

Values are mean \pm SEM

a,b,c indicate significant difference at $5 \%$ level $(\mathrm{P}<0.05)$

$* *$ indicate highly significant value at $1 \%$ level $(\mathrm{P}<0.01)$ 
The mean value of mass activity is presented in figure-13. It showed that, the highest $(3.94 \pm 0.25)$ value of mass activity of semen was found in Holstein-Friesian x Zebu breeds of bulls and lowest (3.12 \pm 0.04$)$ in Red Chittagong breeds of bulls. The value of mass activity of semen in other two breeds was $3.58 \pm 0.10$ and $3.64 \pm 0.09$ for Sindhi $x$ Zebu and Shahiwal $x$ Zebu breeds of bull respectively. There was no significant ( $\mathrm{P}>0.05$ ) difference between Shindhi $x$ Zebu and Shahiwal $x$ Zebu breeds of bulls. The value of mass activity of semen of Shindhi $x$ Zebu and Shahiwal $x$ Zebu breeds of bull differed significantly $(p<0.01)$ from HolsteinFriesian $x$ Zebu and Chittagong breeds of bulls. The value of mass activity of semen of Red Chittagong breeds of bulls significantly $(p<0.01)$ differed from Holstein-Friesian $x$ Zebu breeds of bull.

Reference [17] found higher semen mass activity $(2.10 \pm 0.06)$ in Murrah bulls as compared to crossbred bulls $(1.99 \pm 0.07)$ and reported that the mean mass activity score and percent individual sperm motility were significantly higher $(\mathrm{p}<0.05)$ in Gir bulls $(3.33 \pm 0.11$ and $7.50 \pm 0.89)$ than Jaffarabady buffalo semen $(2.80$ \pm 0.06 and $66.75 \pm 1.04)$.

Figure 4. Graphical presentation of concentration of semen of different breeds of bull

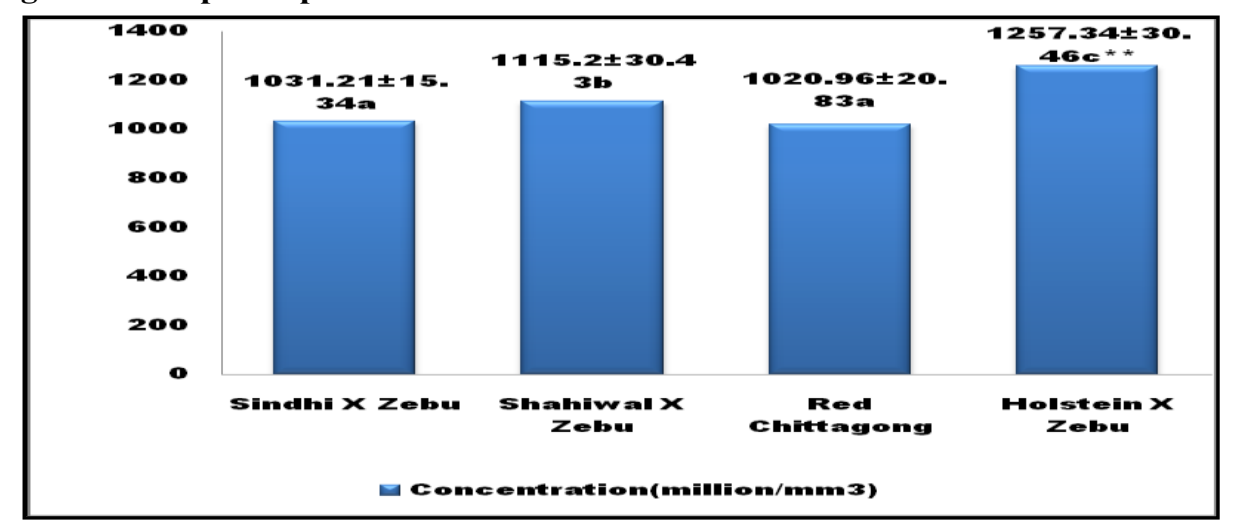

Values are mean \pm SEM

a,b,c indicate significant difference at $5 \%$ level $(\mathrm{P}<0.05)$

** indicate highly significant value at $1 \%$ level $(\mathrm{P}<0.01$

The highest $\left(1257.34 \pm 30.46\right.$ million $\left./ \mathrm{mm}^{3}\right)$ value of concentration of semen was found in HolsteinFriesian x Zebu breeds of bulls and the lowest $\left(1020.96 \pm 20.83 \mathrm{million} / \mathrm{mm}^{3}\right)$ was found in Red Chittagong breeds of bulls. The value of concentration of semen in other two breeds was $1031.21 \pm 15.34$ million $/ \mathrm{mm} 3$ and 1115.20 $\pm 30.43 \mathrm{million} / \mathrm{mm}^{3}$ for Sindhi $\mathrm{x}$ Zebu and Shahiwal $\mathrm{x}$ Zebu breeds of bulls respectively. There was no significant $(\mathrm{P}>0.05)$ difference between Shindhi $\mathrm{x}$ Zebu and Red Chittagong breeds of bull. The value of concentration of semen of Shindhi $x$ Zebu and Red Chittagong breeds of bull differed significantly $(p<0.01)$ from Holstein-Friesian x Zebu breeds and Shahiwal x Zebu breeds of bulls. And the value of concentration of semen of Shahiwal x Zebu breeds of bull significantly $(\mathrm{p}<0.01)$ differed from Holstein-Friesian x Zebu breeds of bulls.

Reference [18] closely support the findings of present study. Referenc [19] reported higher sperm concentration in December and the highest concentration $\left(1000 \mathrm{million} / \mathrm{mm}^{3}\right)$ was obtained in Holstein Friesian cross-breeds of bull. According to Reference [20] the concentration of bull sperm ranges from 800-2000 million $/ \mathrm{mm}^{3}$. Season had no effect on buffalo bull sperm concentration but it increased significantly with the age of the animals [18].

Figure 5. Graphical presentation of pH of semen of different breeds of bull

Values are

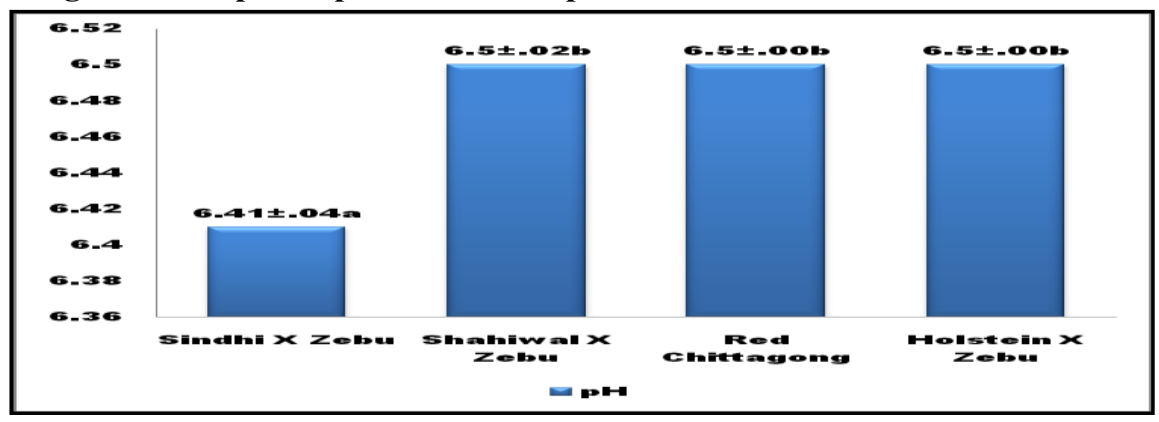

SEM

a,b indicate significant difference at $5 \%$ level $(\mathrm{P}<0.05)$ 
** indicate highly significant value at $1 \%$ level $(\mathrm{P}<0.01)$

Graphical presentation of $\mathrm{pH}$ value of semen of different breeds of bull showed that, there was no significant differences among Shahiwal $\mathrm{x}$ Zebu, Red Chittagong and Holstein-Friesian $\mathrm{x}$ Zebu breeds of bull. But Shindhi $x$ Zebu breeds of bulls were significantly $(\mathrm{p}<0.05)$ differed from Shahiwal $\mathrm{x}$ Zebu, Red Chittagong and Holstein-Friesian $x$ Zebu breeds of bull (Figure-15). The result was found in accordance with references [10], [13] found that average $\mathrm{pH}$ about $6.1-6.5$. The highest $\mathrm{pH}$ was found in summer. Lowering of $\mathrm{pH}$ with lactic acid was demonstrated to immobilize bull sperm [22], [23]. The $\mathrm{pH}$ of seminal plasma ranges from 6.7 to 7.4 , which is common in the domestic species [24] and has the potential to neutralize vaginal acid. The $\mathrm{pH}$ value did not differ significantly between breeds and season.

Figure 6. Graphical presentation of live spermatozoa percent of different breeds of bull

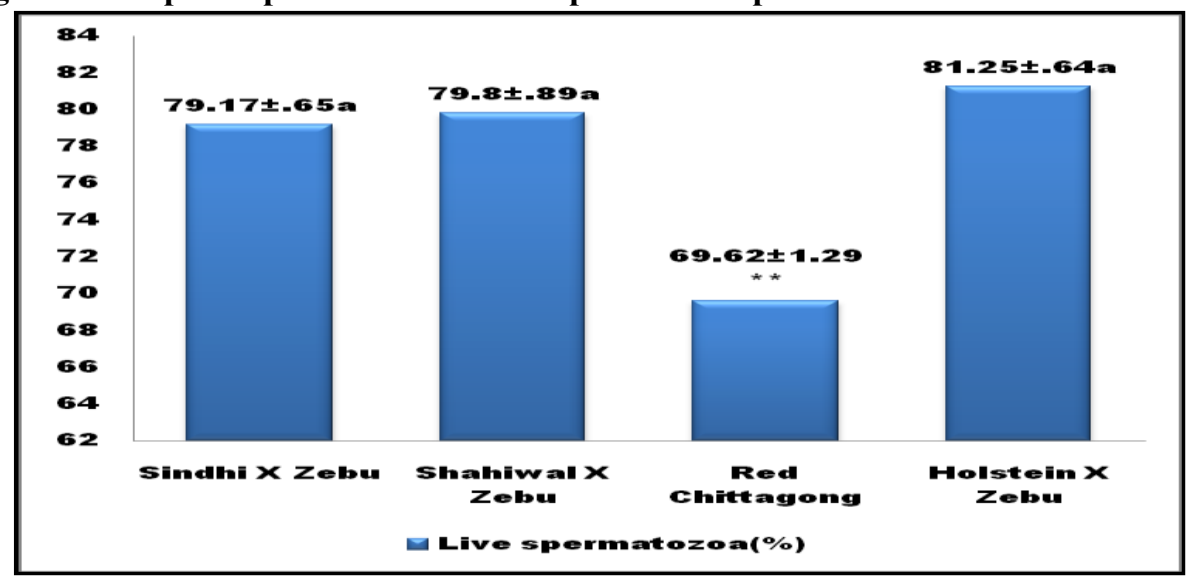

Values are mean \pm SEM

a,b indicate significant difference at $5 \%$ level $(\mathrm{P}<0.05)$

$* *$ indicate highly significant value at $1 \%$ level $(\mathrm{P}<0.01)$

The highest $(81.25 \pm 0.64 \%)$ value of live spermatozoa was found in Holstein-Friesian $\mathrm{x}$ Zebu breeds of bulls and the lowest $(69.62 \pm 1.29 \%)$ was found in Red Chittagong breeds of bulls. The value of live spermatozoa in other two breeds was $79.17 \pm 0.65 \%$ and $79.80 \pm 0.89 \%$ for Sindhi x Zebu and Shahiwal x Zebu breeds of bull respectively. There were no significant ( $\mathrm{P}>0.05$ ) differences among Shindhi $x$ Zebu, Shahiwal $x$ Zebu and Holstein-Friesian x Zebu breeds of bulls. But The value of live spermatozoa (\%) of Red Chittagong breeds of bulls significantly $(\mathrm{p}<0.01)$ differed from Holstein-Friesian $\mathrm{x}$ Zebu, Shindhi $\mathrm{x}$ Zebu and Shahiwal x Zebu breeds of bull. The findings of present study collaborate with the results of references [25], [26] who observed that, the average live sperm percentage for Holstein bull $83.5 \%$ and with a range from $70 \%-90 \%$. The difference between breeds/crosses in live sperm percentage shows that performance of Red Chittagong bull was consistently lower than any other bull.

Figure 7. Graphical presentation of percentage of fertility of different breeds of bull

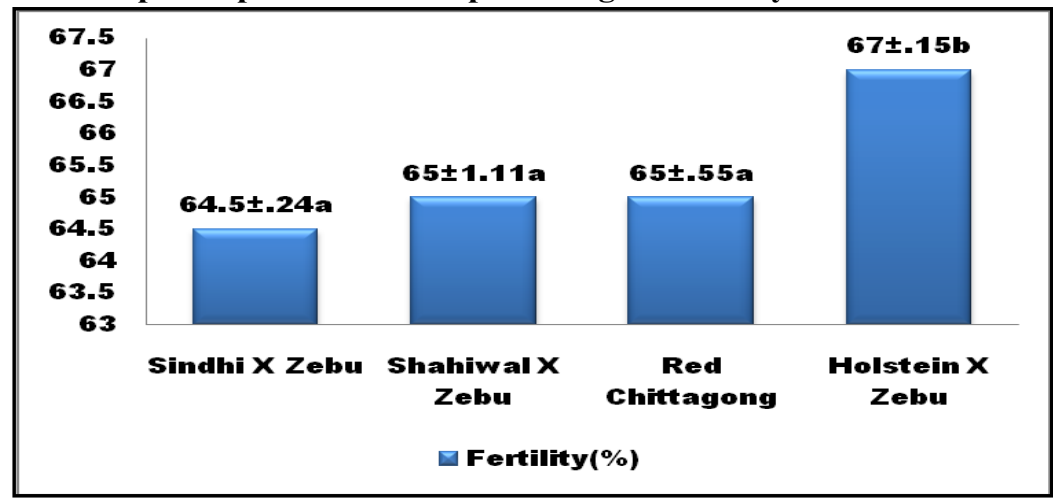

Values are mean \pm SEM

a,b indicate significant difference at $5 \%$ level $(\mathrm{P}<0.05)$

** indicate highly significant value at $1 \%$ level $(\mathrm{P}<0.01)$

The fertility rate of different breeds of bull is depicted in figure-18. It showed that, the highest $(67.00 \pm 0.15 \%)$ value of fertility was found in Holstein-Friesian x Zebu and the lowest $(64.50 \pm 0.24 \%)$ was 
found in Sindhi $x$ Zebu breeds of bulls. The value of fertility in other two breeds was $65.00 \pm 1.11 \%$ and $65.00 \pm 0.55 \%$ for and Shahiwal x Zebu Red Chittagong breeds of bull respectively. There were no significant ( $\mathrm{P}>0.05$ ) differences among Shindhi $x$ Zebu, Shahiwal x Zebu and Red Chittagong breeds of bull. But the value of fertility $(\%)$ of Holstein-Friesian $x$ Zebu breeds of bulls significantly $(p<0.05)$ differed from Shindhi $x$ Zebu, Shahiwal x Zebu and Red Chittagong breeds of bulls.

\section{Conclusion}

The results of the present investigations concludes a breeding soundness evaluation helps in identification of problems of bulls in a bull station. Mean value of semen ejaculate volume, sperm motility, mass activity, sperm concentration, percentage of live sperm and dead sperm , pH, Fertility were $5.81 \pm 0.16 \mathrm{ml}, 66.64 \pm 0.50 \%, 3.59 \pm$ $0.05,1115.97 \pm 16.08 \mathrm{million} / \mathrm{mm} 3,77.62 \pm 0.63 \%, 15 \%$ to $45 \%, 6.48 \pm 0.01,65.37 \pm 0.31 \%$ respectively and these parameter varied from $2.00 \mathrm{ml}$ to $8.50 \mathrm{ml}, 55 \%$ to $75 \%, 2$ to 4,800 million $/ \mathrm{mm} 3$ to $1775 \mathrm{million} / \mathrm{mm} 3,55 \%$ to $85 \%, 6.00$ to 6.70 and $45 \%$ to $80 \%$ for semen ejaculate volume, sperm motility, mass activity, sperm concentration, percentage of live sperm, $\mathrm{pH}$ and Fertility respectively in the examined cattle species. Significantly $(\mathrm{P}<0.01)$ highest volume per ejaculate, sperm concentration, mass activity were found in Holstein cross and lowest in Red Chittagong bull And significantly $(\mathrm{P}<0.05)$ highest live sperm, $\mathrm{pH}$, Fertility rate were found in Holstein cross and lowest in Red Chittagong bull. Holstein- Friesian x Zebu produced better quality of semen than other. So, Holstein cross bulls ranked top and superior among the bulls under investigation.

\section{References}

[1]. J.V. Braun, The role of livestock production for a growing world population, Lohmann Information, 45, $2010,3-6$.

[2]. T.J. Parkinson, Evaluation of fertility in natural service bulls. The Veterinary Journal. 168, 2004, $215-229$.

[3]. Z. Ahmed and T.S. Islam, Cattle breeding programme through artificial insemination in Bangladesh. Central Cattle Breeding Station, Savar, Dhaka, Bangladesh 1987, 61-62.

[4]. E. Bloom, The corkscrew sperm defect in Danish bulls of possible indicator of nuclear fallout, Nordic Veterinary Medicine 30, $1978,1-8$.

[5]. M. J. Nicholson and M. H. Butterworth, A guide to condition scoring of zebu cattle. International Livestock Center for Africa, Addis Ababa, Ethiopia, 1986.

[6]. G.H. Arthur, D.E. Noakes and H. Pearson, Veterinary Reproduction and Obstetrics. $6^{\text {th }}$ edn. The English language book Society and Balliere Tindall, London. 1982,. 517-519.

[7]. F.H. Comaire, S. Huysse, A. Hinting, L. Vermeulen and F. Schoonjans, Objective semen analysis: has the target been reached? Human Reproduction 7, 1992, 237-241.

[8]. E. Elliot, Significance of semen quality. In: Salisbury GW; Van Demark NL and Lodge JR (Eds), Physiology of Reproduction and Artificial Insemination of Cattle, WH Freeman and Company, San Francisco, 1978,. 428-441.

[9]. H.A. Herman, J.R. Michell and G.A. Doak, The artificial insemination and embryo transfer of dairy and beef cattle: A handbook and laboratory manual, $8^{\text {th }}$ edn. Interested Publishers Company, INC, Danville, Llinois, USA 1994, 45-55.

[10]. S. P. Shaha, M. G. S. Alam, M. Khatun and J. U. Ahmed, Breeding soundness of stud bulls, The Bangladesh Veterinarian 25, 2008, 51-61.

[11]. C.R. Sane, S.N. Luktuke, A.S. Kaikini, V.B. Hukeri, B.R. Deshpande, D.P. Velhankar, Artificial insemination of cattle. In: Sane CR, Hukeri VB, Marathe MR (Edn). Reproduction in Farm Animals (Theriogenology). Varghese Publishing House, USA 1994, 524-89.

[12]. M.S. Raja and A.R. Rao, Note the semen characteristics of cross-breed purebred bulls. Indian Journal of Animal Science 52, 1982, 230-232.

[13]. D.P. Mukherjee and G.C. Banerjee, Genetics and breeding of farm animals. Published by Oxford and IBM Publishing Company, Calcutta. 1980. 297-301.

[14]. V.B. Saxena and S.S. Tripathi, Seasonal variation in the incidence of sperm morphological abnormalities in dairy bulls regularly used for Artificial insemination. British. Vet. J. 143,1981, 312-317.

[15]. G.L.N. Igboeli, N. Nwaklor, B.I. Orjii and G.I. Onuora, Seasonal variation in the semen characteristics of Muturo (Bos-brachceros bulls). Animal Reproduction Science 14,1987, 31-38.

[16]. M.A. Hoque, M.R. Amin and M.S. Hussen, Breeding profiles of Sahiwal bulls and native cows in dairy pocket of Bangladesh. Bangladesh J. Anim. Sci. 26, 1997, 147-153.

[17]. A. Pal, P.N Chatterjee and A.K Chakravart, Genetic Study of Dairy Cattle and Buffalo Bulls Based on Growth, Milk Production and Reproductive Traits .Iranian Journal of Applied Animal Science; Volume: 2, Number: 3, 2006, Pages: 239-245

[18]. C.K. Kim, Y.C. Chung and S.H. Kim, Studies on reproductive capacity of Korean native bulls. Effect of age, season, and collection frequencies on semen characteristics in bulls. $5^{\text {th }}$ World Conference on Animal Production, August 14-19, 1983.

[19]. R.W. Everett and B. Bean, Environmental influences on semen output. J. Dairy Sci. 65, 1982, 1303-1310.

[20]. E.S.E Hafez: Artificial insemination. In: E.S.E. Hafez. (Ed), Reproduction in Farm Animals. Lea and Febiger, Philadelphia, 1993, pp. 424-439.

[21]. S Koonjaenak, V Chanatinart, S Aiumlamai, T Pinyopumimintr and H Rodriguez-Martinez, Seasonal variation in semen quality of swamp buffalo bulls (Bubalus bubalis) in Thailand. Asian Journal of Andrology 9, 2007, 92-101.

[22]. T.S. Acott and D.W. Carr: Inhibition of bovine spermatozoa by caudal epididymal fluid. II. Interaction of pH and a quiescence factor. Biological Reproduction 30, 1984, 926-935.

[23]. D.W. Carro, M.C. Usselman, T.S. Acott, Effects of pH, lactate, and viscoelastic drag on sperm motility: a species comparison. Biological Reproduction, 33, 1985, 588-595.

[24]. S.J. Roberts, Veterinary Obstetrics and Genital Diseases, $3^{\text {rd }}$ edn. Stephen Roberts, Woodstock, VT, USA pp. 622, $1986,709$.

[25]. T.L.N Rao and A.R Rao, Fertility and its relationship with semen characteristics in Crossbred bulls, Indian Vet. J. ,56,1979: $33-36$. 